\title{
A Genealogical „Convention« in Biblical Chronography?
}

\author{
By Jack M. Sasson \\ (The University of North-Carolina at Chapel Hill, Dept. of Religion)
}

The purpose of this paper is to focus, once more ${ }^{\mathbf{1}}$, attention on a genealogical procedure which obtained among Hebrew chronographers ${ }^{2}$. Simply stated, this paper will hold that, in some cases, minimal alterations were made in inherited lists of ancestors in order to place

1 The Rabbis of old had noticed the occurence of such a procedure. The following quotation is from Midrash Rabbah: Leviticus tr. J. J. Slotki, 1969, 377-378:

"All sevenths are favourites in the world. The seventh is a favourite above, for there are shamayim, sheme hashamayim, rakia', shehakim, zebul, ma'on, and 'araboth, and of the last-named it is written, Extol Him that rideth upon the 'araboth, whose name is the Lord (Ps. LXVIII, 5). On earth too the seventh is a favourite. For it is called: erez, adamah, arka', ge, ziyyah, neshiyyah, and tebel, and of the last-named it is written, He will judge the tebel with righteousness, and the peoples in His faithfulness (ib. XCVI, 13). The seventh is a favourite among the generations. Thus: Adam, Seth, Enosh, Kenan, Mahalelel, Jared, Enoch, and of him it is written, And Enoch walked with God (Gen. V, 22). Among the Patriarchs the seventh was the favourite. Thus: Abraham, Isaac and Jacob, Levi, Kohath, Amram, and Moses, of whom it is written, And Moses went up unto God (Ex. XIX, 3). Among the children the seventh was the favourite, as it says, David the seventh (I Chron. II, 15). Among the kings the seventh was the favourite. Thus: Saul, Ishbosheth, David, Solomon, Rehoboam, Abijah, Asa, and of the last-named it is written, And Asa cried unto the Lord (II Chron. XIV, 10). Among the years the seventh is the favourite, as it says, The seventh year thou shalt let it rest and lie fallow (Ex. XXIII, 11). Among the septennates the seventh is a favourite, as it says, And ye shall hallow the fiftieth year (Lev. XXV, 10). The seventh is the favourite among the days, as it says, And God blessed the seventh day (Gen. II, 3). Among the months, too, the seventh is the favourite, as it says, IN THE SEVENTH' MONTH, IN THE FIRST DAY OF THE MONTH.

Although U. Cassuto (Commentary on Genesis, I 1961, $281 \mathrm{ff}$.) and B. Jacob (Das erste Buch der Tora. Genesis, 1934, 156-157. 167-168. 309-310 etc.) noted the importance of the number sseven" and its multiples, their discussions did not cover the territory that we propose to explore.

2 There may be other, more esoteric and hence less readily apparent methods of positioning favored personalities in a genealogical tree. M. D. Johnson (The Purpose of the Biblical Genealogies, 1969,32 ) has this to say concerning the chronology of the MT:

"Perhaps the most widely accepted hypothesis regarding the chronology of the MT in its present condition is that the year A. M. 2666 for the exodus represents $262 / 3$ generations of 100 years or two-thirds of a world cycle (Great Year) of 4000 years. This would correspond to the fact that Aaron is the 26 th from Adam while the last two-thirds of a generation is probably represented by Eleazar."

It may be, and this is advanced with due trepidations, that Aaron, and Moses for that matter, is reckoned as 26th from Adam since this number equals the gematria of $\mathrm{YHWH}(\mathrm{Y}=10 ; \mathrm{H}=5 ; \mathrm{W}=6 ; \mathrm{H}=5)$. 
individuals deemed worthy of attention in the seventh, and, to a much lesser extent, fifth position of a genealogical tree.

At the outset, the following cautionary statements should be made: 1- This method of attracting attention to specific individuals is but one of others available to Biblical writers ${ }^{3}$; 2- It should be emphasized that this procedure, which might almost be regarded in terms of a "convention", was neither universally applied, nor slavishly followed; 3 - The origin and development of this "convention« could but be guessed at, since we have no comparative material from Israel's neighbors to control our speculations. It is not unlikely, however, that this procedure was promoted within "intellectual " circles, most probably among individuals who shared a desire to instruct. When organizing their lists, such individuals often had a didactic purpose in mind. The context in which their lists were placed, however, to a great extent determined a framework in which to work. Thus a certain equilibrium was achieved between the genealogist's eagerness to teach worthy lessons and the disciplining exigencies of a narrative. With their freedom somewhat constrained, genealogists, therefore, concentrated their didactic effort on one, or at most, two positions in a genealogical tree. In view of the predeliction that Semites in general, and Hebrews in particular, had for the number "seven" and its multiples, the favoring of the "seventh-position « should prove understandable.

We shall proceed first by analyzing antediluvian lists preserved in Genesis. Seemingly inordinate amounts of space will be devoted to this topic. But this example will permit us, within a relatively controllable context, to speculate on the possible manner in which this "convention" was applied. In order to test our hypothesis, the lines of Shem, the ones of Esau, and those variously recorded for Jacob's descendants will then be discussed. Finally, a proper appreciation of the "seventh-position convention" will allow us to assess conflicting opinions about pedigress preserved in Ruth and I Samuel.

I.

A majority of scholars are generally agreed that the wethite line [of antediluvian ancestors preserved in Genesis 5] is related, in some of the names if not in general treatment, to the Cainite line of IV 17-24, which was traced by a different hand. The two lists point

3 Among these I mention two approaches: a. bestowing unflattering names upon unworthy individuals. Instances drawn from Gen 14 include the names of the kings of Sodom and Gomorrah: Bera' ("In Evil"), and Birsha ("In Wickedness(); b. playing-on-words in manner so obvious that it attracts attention upon an individual. Examples from this method are to be found in this writer's entry in IDB Supplement, 968-970. 
back, therefore, to the same ultimate source ${ }^{4}$. Recently, W. W. Hallo has reminded us of a useful distinction that should be made between the two traditions. Just as the Mesopotamians held parallel, yet distinct, traditions concerning antediluvian sages and antediluvian kings, argues W. W. Hallo, so did the Hebrews recognize two sets of ancestors before the Flood: one provided mankind with its institutions; the other detailed the human links between Creation and the Flood ${ }^{5}$. Paralleling the Mesopotamian concept of antediluvian sages, the Cainite genealogist [hereinafter $\mathrm{K}$ ] sets up his line to include scultural heroesu. It is unfortunate for us that he chose not to detail the specific contribution of Mehûh/îyā’èl, Metûšāèl, and Lemek ${ }^{6}$. Scholars have been forced to propose etymologies for these personal names which best suggest institutional developments. It would be fair to say, however, that many of these proposed hypotheses have not been convincing?.

$\mathrm{K}$ places Lemek in seventh position in his genealogical list. Many traditions probably circulated about this ancestor. The ones chosen for inclusion by $\mathrm{K}$, and by the Sethite genealogist [hereinafter $\mathrm{S}$ ] for this matter (cf. 5 31), make allusions to multiples of seven. Thus, in the so-called "sword song" it is said: wif Cain is avenged sevenfold then Lamech seventy-sevenfold (Torah) « (4 24). Further, K adopts the ascription of three male descendants to the last member of his genealogy, and provides these descendants with definite occupations: shepherding, entertaining ${ }^{8}$, and smithing. $\mathrm{K}$ knows of a female descendant of Lemek, $\mathrm{Na}^{\mathrm{a}}$ amah. But possibly inhibited by the strong tradition of limiting information to only three branches of male descendants, no material is coupled to her name.

Gen 417 contains a curiously worded statement concerning Cain: "When Cain had intercourse with his wife, she conceived and bore Enoch way $(y)$ ehı̂ bōneh 'îr wayyiqrä’ šèm ha'î̀r kešem benô hanōk."

4 Although this quotation comes from E. A. Speiser, Genesis (Anchor Bible 1), 1964, 41 , parallel statements are easily met with in other commentaries.

5 JCS 23 (1970), 57-67. See for convenience, his chart provided in W. W. Hallo and W. K. Simpson, The Ancient Near East, 1971, 32. W. W. Hallo's point was not taken into consideration by J. M. Miller in ZAW 86 (1974), 164ff. See now also R. Borger, JNES 33 (1974), 192-193.

6 Differences in the spelling of names recorded in both Cainite and Sethite lists will not be discussed. See, in general, the commentaries of E. A. Speiser, J. Skinner, Genesis (ICC), 1930; S. R. Driver, The Book of Genesis (Westminster Commentaries), 1926; U. Cassuto, A Commentary on Genesis, I 1961.

7 W. W. Hallo, JCS 23 (1970), 64-65. Consistent with his predisposition to recognize Mesopotamian cities in the list, W. W. Hallo connects Lemek with Larak.

${ }^{8}$ Kinnôv (lyre) and 'úgāb (pipe) represent stringed and wind instruments. Together, they symbolize musical entertainment. 
No doubt a play on the word boneh ("the builder of (i) and benô ("his son"i) helped to distort the syntax. But there is more!

U. Cassuto once noted the close resemblance in construction between Gen 417 and 41-2. Just as the latter verses first spoke of the birth of sons to Adam and Eve, and then proceeded to describe their vocation, Gen 417 must be understood as following a similar pattern. As to the name 'îäd of v. 18, U. Cassuto alluded to, but did not favor, a suggestion that, in my opinion, offers the best solution to the variance between K's 'îrad and S's yered (5 15): a parasonantic pun allowed Enoch, builder of cities ('ir) to be the father of 'î $r \bar{a} d$. This type of appellative, that of a father naming his son after an important event which accompanied the latter's birth, is well-known in Semitic onomastica. In such cases, exact philological equivalence was not always manifest ${ }^{10}$. It is not insignificant, furthermore, that whereas throughout v. 18 the qāl of yälad "to bear" is employed to connect one generation to another, the niph'al of that same verb is exceptionally used here to link Enoch and Irad. Thus, v. 17-18 might have, originally, read as follows: "When Cain had intercourse with his wife, she conceived and bore Enoch. Since he [Enoch] was the builder of a city, he named the city after his son. Thus, 'Irad was born to Enoch. 'Irad (then) bore Mehuya'el ..... I ascribe the awkward appendage of whanōk" at the end of v. 17 to a redactor who, facing a sentence that reproduced straightforward genealogies, attempted to resolve what seemed to him a repetition of information about Enoch.

As was convincingly demonstrated by J. J. Finkelstein and A. Malamat, S's list conforms in shape and spirit to a genealogical tradition which seems common to West Semitic folk ${ }^{11}$. Such istock genealogies « as these lists could be called, did not aim to describe cultural achievements, but were satisfied to record the order and the ultimate age of mankind's ancestors. Generally they consisted of one-dimensional, that is vertical, compilations of worthy patriarchs. Among the Hebrews, the antediluvian ancestors were remembered by names that differed only slightly from those of K's seven "cultural heroes". Three names, however, are found only in S: Seth, Enosh and Noah.

$S$ begins his list with words and in a style that recall the creation narrative. He then records the age of an ancestor at the moment of his elder son's birth, notes the number of years remaining before his

9 U. Cassuto, Genesis, 23. On parasonantic puns, see IDB Supplement 969. Following W.W. Hallo, JCS 23 (1970), 64, some scholars have adopted the equation Eridu = 'Irad.

${ }^{10} \mathrm{Cf}$. Gershom, son of Moses, whose name is related to gër vresident alien «, Ex 222.

11 J. J. Finkelstein, JCS 20 (1966), 116; A. Malamat, JAOS 88 (1968) (=Essays in Memory of E. A. Speiser, 1968), 163-173. See the critique of R. R. Wilson in JBL. 94 (1975), 169-189. 
death, and concludes with his total life span. In only two cases was this pattern altered; once to add information about Enoch $(522.24)$ the other (usually ascribed to J) to promote an etymology for the name born by the last antediluvian ancestor, Noah (5 29). When set next to each other, the lines of $\mathrm{K}$ and $\mathrm{S}$ appear as follows:

$\mathrm{K}$

$\mathrm{S}$

'Ādām

Šet

1. 'Ādām

(1) 'Enôš

II

2. Qayin

(2) Qenān

III

3. Hanôk

(3) Mahalal'ēl

4. 'îrād

5. Mehûu/îyāēēl

(4) Yered

IV

(5) Ḥanôk

$\mathrm{V}$

6. Metûšāēēl

(6) Metûšelah

(7) Lemek

VI

VII

7. Lemek

(7)

VIII

IX

\section{$\Gamma$}

Yābāl Yûbāl Tûbal-qayin Na'amāh

Nōaḥ

$\mathrm{x}$

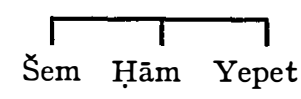

It has often been noted that Enosh, third in position, was considered by S as a "repeater-of-birth " (to borrow a term from Pharaonic Egypt). His name meaning "man" appeared as a synonym of "Adam". Hence he too was, in a sense, the founder of the human race ${ }^{12}$. It may be that the mysterious statement of 426 "It was then that men began to invoke YHWH by name" (which is attributed to $\mathrm{J}$ by some and to $\mathrm{P}$ by others) was intended, at least partially, to highlight the primacy of Enosh even in the cultic beginnings of mankind.

Enoch stands third in position in K. But in S, he is placed seventh. This change, almost certainly must have been due to the fact that important material concerning Enoch was remembered; "Enoch walked with God 300 years ... Enoch walked with God and then he was no more, for God took him " $(522.24)$. As it is, except for an insertion to explain the name of Noah, one that is usually assigned to J, no other personality in $\mathrm{S}$ is provided with information.

In placing Enoch in 7th position, $\mathrm{S}$ was forced to alter the succession of ancestors from the pattern he inherited. In this, he attempted to make minimal changes. Qenān/Qayin, Yered/'Irād, Metûšelaḥ/ Metûšāèl, Lemek, and, to a certain extent, 'Ādām were kept in their proper order. By exchanging the slots reserved for Enoch and Mahalal'èl (K's Mehûu/îyāèlel), S succeeded not only in placing Enoch in a favored position in the stock-genealogy of mankind's ancestors, but

12 U. Cassuto, Genesis, 246; J. Skinner, Genesis, 26. 
also in keeping Mahalal'èl in 5th position, the same as that held by Meḥ̂u/îyā'èl in K's line.

Biblical genealogists, as is argued here, oftentime display a definite predeliction for placing in the seventh-position personalities of importance to them. It is likely that such a convention was but one of many employed by ancient chronographers. In order to test this hypothesis, I shall apply its tenets to three major geneological trees preserved in the MT.

A. The lines of Shem. Gen 11 10-26 preserves another table of ancestors which follows the pattern of "stock-genealogy« ten numbers deep. The line of last person in this list, as usual, spreads horizontally to divide into three branches.

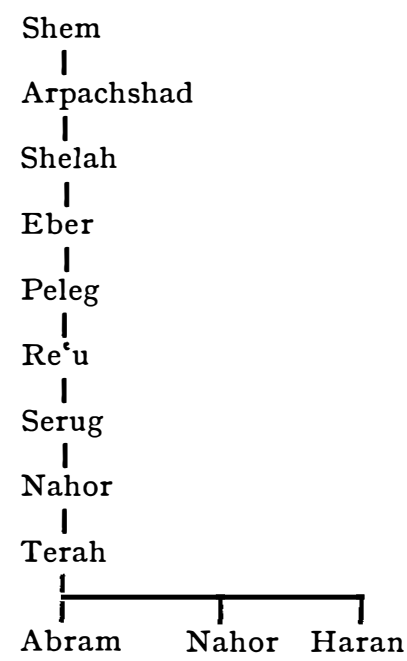

In this pedigree, Eber is reckoned as the 14 th $(2 \times 7)$ since creation and the seventh descendant of Enoch ${ }^{\mathbf{1 3}}$. He, of course, was of prime importance since his was the name by which the Hebrews became known ( $\left.{ }^{\mathrm{i}} i b r \hat{\imath}\right)$. Furthermore, the author of this list $(\mathrm{P})$ must certainly have known the material which $\mathrm{J}$ collected about this eponymous ancestor: "Two sons were born to Eber: the name of the first was Peleg, for in his [Eber's] days the earth split asunder«(Gen 10 25) ${ }^{\mathbf{1 4}}$.

13 It may be of significance that Nimrod, remembered in a striking proverb (Gen 109 ), was seventh from Enoch.

14 As in the case of Enoch (Gen 4 17) discussed above, the event commemorated by the naming a child "Peleg" must have occured in the lifetime of the father, that is Eber. It is not possible to translate with assurance $k \hat{\imath}$ beyāmayw niplegāh $h \bar{a} \bar{a} \mathbf{a} e s ̦$ (Gen 10 25). To begin with, the $\mathrm{N}$ of pälag occurs only in this allusion (cf. I Chr 1 19). Most commentators connect with the division of mankind as reported in Gen 10. I am remin- 
The great patriarch Abraham is reckoned as the seventh since Eber, the tenth since Shem and the twentieth since Adam. It is interesting in this respect to note that LXX (cf. also Luke 3 36) expands Shem's genealogy by inserting "Kenan" between "Arpachshad" and "Shelah". While this addition would place Shelah, not Eber, in the favored fourteenth position, it does permit Abraham to be reckoned as the 21 st $(3 \times 7)$ since Adam, but would still keep him in seventh-position from Eber. As argued by A. Malamat ${ }^{15}$ this expansion of Shem's line might have attempted to promote Terah, who is also recorded in Gen 1126 as possessed of horizontal line which divides into three branches, as the last member, that is the tenth, of Shem's stock genealogy. Moreover, the descendants of Terah seem to have been limited in number to twenty-one males for each of three generations that follow $^{\mathbf{1 6}}$. This is computed as follows:

21st generation Sons of Nahor (Gen 22 20-24) ${ }^{17}$

Sons of Abraham (Gen 1615212252 )

Sons of Haran (Gen 11 26)

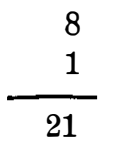

ded, however, of Manetho's account concerning a king of the 2nd (Egyptian) Dynasty: "Boêthos (reigned) for thirty-eight years. In his reign a chasm opened at Bubastis. Many perished." (Quoted from W. B. Emery, Archaic Egypt, 1961, 255.)

15 A. Malamat, Essays ... E. A Speiser, 165-166.

${ }^{16} \mathrm{Abra}(\mathrm{ha}) \mathrm{m}$ is also reckoned as fathering three branches: Ismaelites, Israelites (via Isaac), and descendants of Keturah. Furthermore, the total of male descendants of Abraham, to the third generation is 49 (i. e. $7 \times 7$ ):

\begin{tabular}{|c|c|c|}
\hline 1st generation & Son of Sarah & 1 \\
\hline & Son of Hagar & 1 \\
\hline & Sons of Keturah & 6 \\
\hline & & 8 \\
\hline 2nd generation & Sons of Isaac & 2 \\
\hline & Sons of Ishmael & 12 \\
\hline & $\begin{array}{l}\text { Sons of Jokshan } \\
\text { and Midian }\end{array}$ & 7 \\
\hline & & 21 \\
\hline 3rd generation & Sons of Jacob & 12 \\
\hline & Sons of Esau & 5 \\
\hline & Sons of Dedan & 3 \\
\hline & & 20 \\
\hline & grand total & 49 \\
\hline
\end{tabular}

17 The mention of Aram, son of Kemuel (son of Nahor) (Gen 22 21) is considered a gloss by most commentators; cf. J. Skinner, Genesis, 333, and Gen 1022 . The pattern of twenty-one descendants would not obtain were one to include the (grand) sons of Lot, Moab and Ben-Ami, in either the 2 nd or 3rd generations. The account 


\begin{tabular}{clr} 
22nd generation & Sons of Ishmael (Gen 25 12-16) & 12 \\
& Sons of Isaac (Gen 25 24-26) & 2 \\
& Grandsons of Keturah (Gen 25 3. 4) & 7 \\
\cline { 2 - 2 } 23rd generation & & 21 \\
& Sons of Esau (Gen 36 4-5) & 5 \\
& Sons of Jacob (plus Dinah) ${ }^{18}($ Gen $29-30)$ & 13 \\
& Great-grandsons of Keturah (Gen 25 3) & 3 \\
& & 21
\end{tabular}

B. The Sons of Esau. Gen 36 contains various lists of the descendants and clans that issued from Esau/Edom. Traditions concerning the wives and in-laws of Esau varied (Gen 363289369 ). In attributing Hittite (i. e. Syrian), Horite, and Ishmaelite ancestry to the maternal side of Esau's lineages, the genealogist provided an explanation for the fact that Israel was to become the mortal enemy of some of this brother's descendants.

The Edomite lists are divided up as follows ${ }^{20}$ :

\begin{tabular}{|c|c|c|}
\hline (A) & $\begin{array}{l}\text { Gen } 3611-14 \\
\text { Descendants }\end{array}$ & $\begin{array}{l}\text { Gen } 36 \text { 15-18 } \\
\text { (B) Clans }\end{array}$ \\
\hline \multirow[t]{7}{*}{ Adah $\rightarrow$ Eliphaz $\rightarrow$} & Teman & Teman \\
\hline & Omar & Omar \\
\hline & Zepho & Zepho \\
\hline & Gatam & Kenaz \\
\hline & Kenaz & Korah \\
\hline & Amalek & Gatam \\
\hline & & Amalek \\
\hline Basemath $\rightarrow$ & Nahath & Nahath \\
\hline \multirow[t]{3}{*}{ Reuel $\rightarrow$} & Zerah & Zerah \\
\hline & Shammah & Shammah \\
\hline & Mizzah $^{21}$ & Mizzah \\
\hline \multirow[t]{3}{*}{ Oholibamah $\rightarrow$} & Yeush & Yeush \\
\hline & Yalam & Yalam \\
\hline & Korah & Korah \\
\hline
\end{tabular}

preserved in Gen 19 30-38, possibly foreign in origin, does not lay within the main genealogical traditions. Admittedly, these exceptions weaken our reckoning for the 23rd generation.

18 Dinah, as we shall see, plays a role in genealogical lists. On the possibility that she might have represented a tribe, see G. Fohrer, BZAW 115, 1969, 100-101. Note, also, R. de Vaux, Histoire ancienne d'Israël: La période des juges, 1973, 39.

19 These are listed as nations, not as individuals.

${ }^{20}$ W. J. Horwitz, CBQ 35 (1973), 69-71, too easily trims the list of Horite tribes to twelve.

21 The ^doggerel" quality of the names given to Reuel's sons have been noted by commentators, cf. J. Skinner, Genesis, 431. 
In the above lineage, the sons of Oholibamah are placed on the same level as Adah's and Basemath's grandsons. The reason for this is obscure. It may be that the name of an intermediary link was lost. No changes are recorded in the relative order of the first three grandchildren of Adah, the four grandchildren of Basemath, and the three sons of Oholibamah. The major difference between A and B is found in the insertion of "Korah" in B's fifth position. It is not clear why Korah, whose namesake is repeated at the end of both lists, was chosen for the particular honor. We should not imagine that genealogists hesitated to focus attention on villains, especially pre-eminent ones. The case of Dathan and Abiram, seventh from Abraham and fifth from Jacob through Reuben (Num 269) is especially interesting in connection with Korah. However, E. Meyer long ago plausibly proposed to find among the Edomites an origin for the famous Korahite guild of musicians ${ }^{22}$. Finally, it should be noted that, as the last son of Oholibamah, Korah secured a spot as the fifth son of Esau. I Chr 135 lists him as such. Be that as it may, the interpolation of Korah's name increased the descendants of Esau's first wife, Adah, to seven. This duplicates the number of children Leah, Jacob's first wife, presented her husband. But more important, it permitted Amalek, Israel's foremost foe, to be placed in the seventh slot. Even in (A), Amalek was accorded special, perhaps derogatory, comments (Gen 36 12): his mother Timnah (but cf. 36 22) was but a concubine of Eliphaz. Curiously enough, the author of I Chr 136 inserted "Timnah" in sixth position of Eliphaz's line, no doubt to fulfill a strong tendency to position Amalek as seventh.

I cannot offer an adequate explanation for the switch in position displayed by Gatam and Kenaz, unless it be that the latter, ancestor of the heroic Caleb and Othniel, was granted the fifth slot in a genealogical tree. Gatam, it could be noted, plays no role that was remembered in the Bible.

The genealogy of Seir the Horite (Gen 36 20-30) is recorded in a less elaborate style than that of Esau. Seir is reported fathering seven sons, one daughter (Timnah, see above), and twenty grandchildren. In all, that is twice the number of descendants allotted to Esau in list (B).

C. The Children of Jacob. On a number of occasions, Biblical texts allude to the sons of Jacob, either as individuals or as tribes. In the following, we shall note whether the genealogical "convention" described above had any effect, in some cases at least, on the order in which the sons of Jacob were enumerated. The matter of date, place or origin, and source of each one of these lists is of secondary importan-

${ }^{22}$ Cf. J. Skinner, Genesis, 432. 


\begin{tabular}{|c|c|c|c|c|c|c|c|c|c|c|c|}
\hline $\begin{array}{l}\text { List } \\
\text { Position }\end{array}$ & $\begin{array}{c}\text { (a) } \\
\text { Gen } \\
29-30\end{array}$ & $\begin{array}{c}\text { (b) } \\
\text { Gen } \\
3523-26\end{array}$ & $\begin{array}{c}\text { (c) } \\
\text { Gen } \\
46\end{array}$ & $\begin{array}{c}\text { (d) } \\
\text { Gen } \\
49\end{array}$ & $\begin{array}{c}(\mathrm{e}) \\
\text { Ex } \\
12-4\end{array}$ & $\begin{array}{c}\text { (f) } \\
\text { Num } \\
15-16\end{array}$ & $\begin{array}{c}\text { (g) } \\
\text { Num } \\
120-43\end{array}$ & $\begin{array}{c}(h)^{4} \\
\text { Num } \\
134-15\end{array}$ & $\begin{array}{l}\text { (i) } \\
\text { Num } \\
26\end{array}$ & $\begin{array}{c}(\mathrm{j})^{\mathbf{5}} \\
\mathrm{Dtn} \\
33\end{array}$ & $\begin{array}{c}\text { (k) } \\
\text { I Chr } \\
21-2\end{array}$ \\
\hline 1st & $\mathrm{R}$ & $\mathrm{R}$ & $\mathrm{R}$ & $\mathrm{R}$ & $\mathrm{R}$ & $\mathrm{R}$ & $\mathrm{R}$ & $\mathrm{R}$ & $\mathrm{R}$ & $\mathrm{R}$ & $\mathrm{R}$ \\
\hline 2 nd & $\mathrm{S}$ & $S$ & $\mathrm{~S}$ & $S$ & $\mathrm{~S}$ & $S$ & $\mathrm{~S}$ & $S$ & $S$ & $Y^{\prime}$ & $S$ \\
\hline $3 \mathrm{rd}$ & L & L & L & L & L & $\mathrm{Y}$ & G & $\mathrm{Y}$ & G & $L^{\prime}$ & L \\
\hline 4th & $\mathrm{Y}$ & $\mathrm{Y}$ & $\mathrm{Y}$ & $\mathrm{Y}$ & $\mathrm{Y}$ & I & $\mathrm{Y}$ & I & $\mathrm{Y}$ & $\mathrm{B}^{\prime}$ & $\mathrm{Y}$ \\
\hline 5th & D & I & I & $Z$ & I & $Z$ & I & $\mathrm{E}: Z^{*}$ & I & $\int^{\mathrm{E}}$ & I \\
\hline 6th & $\mathrm{N}$ & $Z$ & $Z$ & I & $Z$ & $\mathrm{E}$ & $Z$ & $\mathrm{~B}: \mathrm{M}^{*}$ & $Z$ & M & $Z$ \\
\hline 7th & G & $\mathrm{J}$ & G & D & B & M & $\int^{E}$ & $\mathrm{Z}: \mathrm{E}^{*}$ & $\int^{M}$ & $Z^{\prime}$ & D \\
\hline 8th & A & B & A & G & D & B & l & $\mathrm{M}: \mathrm{B}^{*}$ & C & I & $\mathrm{J}$ \\
\hline 9 th & I & D & $\mathrm{J}$ & A & $\mathrm{N}$ & D & B & D & B & $G^{\prime}$ & B \\
\hline 10 th & $Z$ & $\mathrm{~N}$ & B & $\mathrm{N}$ & G & A & D & A & $\mathrm{D}$ & $\mathrm{D}^{\prime}$ & $\mathrm{N}$ \\
\hline 11th & $\mathrm{J}^{1}$ & G & D & $\mathrm{J}$ & $\mathrm{A}^{2}$ & G & A & $\mathrm{N}$ & A & $\mathrm{N}^{\prime}$ & G \\
\hline 12 th & & A & $\mathrm{N}$ & B & & $\mathrm{N}^{3}$ & $\mathrm{~N}$ & G & $\mathrm{N}^{3}$ & $A^{\prime}$ & A \\
\hline
\end{tabular}

Remarks on Chart:

1 Benjamin was not born yet.

2 Joseph in Egypt when Eisodus takes place.

${ }^{3}$ Levi not accounted as tribe.

${ }^{4}$ Starred $\left({ }^{*}\right)$ eponyms are reconstructed, see below.

${ }^{5}$ Simeon not listed, (') after name indicates blessing preceded by "of $(x)$ he said.. 
ce to us. For this reason it is best at the outset to refer to R. de Vaux's excellent treatment of these questions in Histoire ancienne d'Israël: La Periode des Juges ${ }^{23}$. Listings in Num 2. 7. 10. 13 Dtn 25 Jos 13-19 Ez 48 I Chr 1227 will not be considered as the order of tribes preserved there followed geographical, quadrantal, or utopian arrangements. That of Jud 5 ("Song of Deborah «), is too exceptional to be taken into account here. The listing in the "blessing of Moses« (Dtn 33) will be given below, but the writer forewarns that he is stumped by it.

In the following chart the eponyms are given by their acronymic abbreviation: A(sher), B(enjamin), D(an), E(phraim), G(ad), I(ssachar), J(oseph), L(evi), M(anasseh), N(aphtali), R(euben), S(imeon), Y(Judah), $Z$ (ebulon).

List (c). Gen 46 8-25 records the number of persons that descended to Egypt along with Jacob. Scholars have rightly stressed the "artificiality" of this list whose main aim is to present, somewhat imprecisely at that, the Hebrew as a community of 70 males (cf. Ex 241.9 Gen 10 Num 1116 Luke 10 1.17). The use of the number seven, and multiples thereof, is not unobtrusive. Rachel's descendants (7) and those of Bilhah (14) are added up to $21(3 \times 7)$; while those of Leah (33) and her maid Zilpah (16) are added up to $49(7 \times 7)$. It is not surprising, therefore, to note that Gad, whose gematria is 7 (gimel $=3$; daleth $=4$ ) is placed in seventh position. Furthermore, he is the only one in this list who is recorded as bearing seven sons.

List (a). The basic purpose of Gen $2931-3024$ is twofold: firstly, to propose an historical and chronological framework for the birth of Jacob's sons; secondly, to propose an etymology for each one of the eponyms and to link that explanation to a narrative of events that transpired before Jacob's return to Canaan ${ }^{24}$. Since Benjamin was not to be born until Jacob's arrival to the promised land, the number of his children was preserved as twelve by noting the birth of Dinah. Gad is placed as seventh very likely for the same reasons as the ones outlined above.

Lists ( $i),(g)$, and $(f)$. The census lists preserved in (g- Num $120-43$ ) and (i- Num 26 5-51) follow nearly identical patterns. That some sort of dependence existed between list (c- above) and (i) has been recognized by S. R. Driver ${ }^{25}$. But some important changes are readily apparent. Firstly, Levi, no longer considered a part of the tribal "system", was not reckoned in the census. Secondly, the seventh posi-

${ }^{23}$ See especially 37-64. Note also, D. N. Freedman, Unity and Diversity (ed. by H.

Goedicke and J. J. M. Roberts, 1975), $31 \mathrm{n} .70$, and A. D. H. Nayes, Israel in the

Period of the Judges (S. B. Th. 2/29), 1974, 16-34.

24 But see N. Sarna, Understanding Genesis, 1966, 198-199.

25 S. R. Driver, Genesis, 365 
tion was given to Manassah probably because in (i) his tree is the only one which, beginning with Joseph (v. 28), is recorded as being seven generations deep; all others hardly reach beyond the second or third generation. The reason for extending Joseph's line via Manasseh is obvious. The genealogist was eager to link this eponymous ancestor to the well-known and juridically important incident of Zelophehad's daughters (cf. Num 24 1-17). Thus, he shows the following: JosephManasseh-Machir-Gilead-Hepher-Zelophehad-five daughters. Thirdly, with Manasseh given the favored position, it was no longer possible for Gad to retain the seventh slot as he did in (c). Since Gad continued to display the same qualities that attracted attention in (c), he was placed in the space normally occupied by Levi. This decision had the further merit of limiting any distortion in the line to a minimum. Benjamin, allowed his usual position, was placed immediately after Ephraim. For reasons that are unclear to me, Asher, who was displaced by Ephraim, was sandwiched between Dan and Naphtali.

List (g- Num 1 20-43) is obviously related to (i) with which it differs only in the switch in position between Ephraim and Manasseh. I have no satisfactory solution for this, unless it be that, for obscure reasons, (g)'s seventh position was patterned after (h) (see below).

List (f- Num 1 5-16) may have been dependent on (i), for it too does not mention Levi and gives pride of place to one of Joseph's sons. In this line, however, Gad did not occupy Levi's slot. Rather it was filled by moving Judah up one step. The last, it should be noted, was represented in this list by Nahshon, progenitor of kings. Manasseh, whose line in (i) is carried into the period of Zelophehad's daughters is placed in the seventh position. I have no suggestions for the curious sandwiching of Zilpah's son - given in reverse order! - between Bilhah's Dan and Naphtali.

List ( $h$ - Num 13 4-15) contains the names of the nesî̀ $2 m$ sent to scout Canaan. As has long been maintained, the order preserved in the MT is to be corrected by simply placing v. 10-11 before v. 8. This is so because the beginning of v. 11, "From the tribe of Joseph ...." presumes a sequence in which Ephraim follows Manasseh ${ }^{26}$. Both orders are given in the chart, with the corrected one starred (*).

A glance at the trees of (f) and the reconstructed (h) clearly indicates their close affinity. A minor change is displayed in the positions assigned to the sons of Bilhah and Zilpah. Effectively, however, the difference is limited to a transposition of Naphtali and Gad.

Whereas (f) had Manasseh placed in seventh position, possibly under the influence of (i), (h) had a distinct and compelling reason to give the preferred slot to Ephraim, for that tribe's delegate to the

26 R. de Vaux, Histoire ancienne d'Israël, 43. 
scouting mission was Hosea son of Nun, better known, after v. 16, under the name Joshua.

Lists (b) and (e). List (b- Gen 35 23-26) also places Joseph in seventh position. This list follows a strict order in naming the issues of Leah, Rachel, Bilhah, and Zilpah. It is interesting that without the linguistic and numerical elaborations which characterized the work of (a) and (c), there was no need to place Gad in seventh position. Freed from this exigency, the genealogist of (b) was pleased to record the sons of Rachel and those of her handmaid Bilhah, before returning to Leah's children through Zilpah.

List (e- Ex 1 2-4) depended on (b). But due to the circumstances of the narration, it was necessary to mention neither Joseph's name nor those of his sons. The genealogist of (e) simply pushed up his tree one slot. In this instance, I do not attach much significance to Benjamin's occupation of the seventh position.

List (d) and ( $k$ ). The "Testament" of Jacob is, as is generally held, made up of poems on individual tribes. Those poems, to a large degree, antedate the monarchial period. However, their arrangements within a genealogical framework was very likely accomplished not too long before the exile.

List (d) exhibits a number of oddities. The sons of Leah, with Zebulon preceding Issachar, and the sons of Rachel are positioned respectively first and last. Those of Bilhah are split to include the sons of Zilpah. A similar concept is exhibited in (k- I Chr 2 1-2), with the position of Rachel's sons exchanged for that of Zilpah's children. Note, however, that in both (d) and (k), Dan occupies the seventh slot. That the seventh-position is favored in (d) is fairly certain for it is highlighted by a very unusual cri-de-coeur: "For your salvation I am waiting, oh Lord" (v. 18).

Though it is clear that the seventh slot was favored in (d), it is not readily apparent why Dan was given the honor to occupy it. Two thoughts come to mind. First, in the narrative account of the birth of Jacob's son, list (a), Dan is fifth in order. We have noted a certain tendency to have a switch from fifth to seventh position (and viceverse). This would presume that the organizer of (d) knew the accounts recorded in (a). Secondly, aside from Judah and Joseph whose blessings were doctored by monarchical sympathizers, Dan is singled out as the sole eponymous ancestor who is remembered by two separate blessings.

A further piece of speculation: (d) contains a rare example of Zebulon preceeding Issachar in geneological order. The only other example occurs in the unusual "Blessing of Moses" (j), an example which, incidentally, contains poetic themes concerning Zebulon strikingly reminiscent of those in (d). Most unusual also is the reference in v. 13 to the fact that "Zebulon shall dwell by the seashore .... Zebu- 
lon, according to all our evidence, was a landlocked tribe. Recently, Y. Yadin has rather imaginatively reconstructed the early history of the Danites in which he takes the latter to have been a maritime nation ${ }^{27}$. If Y. Yadin's hypothesis proves to be true, Zebulon's connection with the sea might have resulted from his occupying the fifth position in (d), a position held by Dan in (a).

\section{III.}

A. When Ruth of Moab bore Obed, the child was to perpetuate the memory of Mahlon, Ruth's deceased husband. However, the genealogy at the end of ch. 4, v. 18-22, clearly reckons Boaz as Obed's father. For this reason many scholars consider the list to have been appended by a later hand, one which was eager to link David to the deeds of Boaz and his Moabitess. Other scholars counter with the belief that Ruth's child was considered by the Bethlehemites (cf. v. 12) as belonging both to the family of Mahlon, i. e. Elimelech, and that of $\mathrm{Boaz}^{28}$.

A proper application of the "seventh-position" hypothesis would indicate that the pedigree of 4 18-22 was drawn specifically for inclusion in the book of Ruth. For, as we proceed from father to son, we note that Boaz, hero of the story, occupied the seventh slot. In order to preserve Boaz in this position, moreover, the genealogist of Ruth was forced to begin his line, not with the name of the eponymous ancestor Judah, but with that of the lesser luminary Perez. Since, as it has been cogently argued by D. R. G. Beattie, Ruth was not concerned with "levirate "marriage ${ }^{29}$, there remains little which might adequately explain Perez's inclusion in v. 12 ("May your house be like the house of Perez, whom Tamar bore to Judah . . . (1). It is here suggested that this mention of Perez in v. 12 was anticipatory, even secondary, possibly inserted to explain a list which has seemingly neglected to provide a crucial link in the line of ancestors: Judah ${ }^{29_{\mathbf{a}}}$.

B. "There was a man of Benjamin whose name was Kish, the son of Abiel, son of Zeror, son of Becorath, son of Aphiah, a Benjaminite, a man of wealth; and he had a son whose name was Saul . . «It will be noticed that the translation of I Sam 9 1-2 a, which comes from RSV, does not do full justice to the Hebrew text. The MT of v. 1 ends with

\footnotetext{
27 Australian Journal of Biblical Archaeology 2 (1968), 9-23; C. H. Gordon, VT Supplement 9, 1963, 21-22.

${ }^{28}$ For discussion of the issues and convenient bibliography, see H. H. Rowley, The Servant of the Lord, $1965^{2}, 193-194$. See now my commentary to Ruth (1978), $\S$ xiv.

29 VT 24 (1974), 251-267; JSOT 5 (1978), 39-68.

29a S. Parker, JBL 95 (1976), 30.
} 
the following: . . . ben-'aphâh̆ ben-'î̌s yemînî gibbôr hấyil. Literally this means: \#. . . the son of Aphiah, the son of a Yeminite, a landowner". RSV follows most commentators and translators when it deletes either 'îs or the last ben. H. P. Smith, in his ICC commentary to this verse, offers the usual explanation: »ben-'îs yeminn $\hat{\imath}$ is not without analogy, at least ' $\hat{s}$ yemin $\hat{\imath}$ is found in $2 \mathrm{~S} .20_{1}$ Est $2_{5}$. But it is unusual to terminate a genealogy by saying son of a Benjaminite. It is probable that $b e n$ is the error of a scribe who expected to continue the genealogy. . $^{30}$

But, to be strictly accurate, "son of a Benjaminite " actually begins the pedigree, which except for the name of Saul is here given backwards: Saul $\leftarrow$ Kish $\leftarrow$ Abiel $\leftarrow$-Zeror $\leftarrow$ Bechorath $\leftarrow$ Aphiah $\leftarrow$ Benjaminite. Thus, to place Saul, the protagonist of the ensuing narration, in seventh-position, the genealogist began, with the forgotten name of a Benjaminite ancestor. Again, a proper application of our theory would indicate that any emendation of I Sam 9 11-26 would be mistaken $^{31}$.

Der Verf. will zeigen, daß in einigen Fällen kleine Änderungen an überkommenen Ahnenlisten vorgenommen worden sind, um bevorzugte Personen an die siebte Stelle eines Stammbaums zu setzen. Beispiele dafür werden Gen 4-5. 11.36 I Sam 9 1-2a Ruth 4 18-22 und den Aufzählungen der israelitischen Stämme entnommen.

L'A. se propose de montrer que, dans quelques cas, des listes d'ancêtres ont été légèrement retouchées en vue de donner à des personnes que l'on voulait mettre en avant la septième place de l'arbre généalogique. Il examine à cet effet Gen 4-5.11. 36 I Sam 9 1-2a Ruth 4 18-22 et les listes des tribus israélites.

${ }^{30}$ Samuel, 1899, 60-61.

${ }^{31}$ For a compact discussion of geneological lines in the New Testament, from the seventh-generation point-of-view, see the author's short entry in IDB Supplement, sub "Generation-Seventh", 354-356. 